\title{
Administration of English Language Programme in Nigerian Higher Institutions: Problem, Issues and Suggestion
}

\author{
Ogunode Niyi Jacob \\ Federal University Wukari, Taraba State. Nigeria \\ ogunodejacob@gmail.com
}

\begin{abstract}
Received : 2020-11-16
Revised : 2020-11-26

Accepted : 2020-11-27
\end{abstract}

ARTICLE HISTORY

\section{KEYWORDS}

Administration

Challenges

English Language Programme

\begin{abstract}
The article discussed the problems facing the administration of English language programme in the Nigerian higher institutions. Secondary data was used to support the points raised in the article. The secondary data were sourced from print material and online publication by recognized institutions and individual author. The problems facing the administration of English language programme in Nigerian higher institution include; inadequate funding, inadequate English language lecturers, inadequate English language laboratories, poor research in English language programme, brain-drain, strike actions, poor capacity development of English language programme lecturers and institutional corruption. For effective administration of English language programme in the Nigerian higher institutions, the paper hereby recommends: that the government should increase the funding of English language programme, employment of more English language lecturers, provision of adequate infrastructural facilities, implementation of agreement with unions, effective staff development programme, effective motivation policy to prevent brain-drain and fight all the institutional corruption in the higher institutions.
\end{abstract}

\section{Introduction}

Higher education is the post-secondary school education designed for the production of manpower. Higher education is an education that awards certificates after the completion of the programme. Higher education is the education that deals with teaching programme, research programme and community service programme. Higher education is the peak of educational institutions and it is an organized educational system that is meant to support the social, economic and political development of the country. Obanya (1999) observed that higher education includes post-secondary institutions such as the polytechnics and colleges of education. "Higher Education" includes all forms of professional institutions drawing from the available pool of persons who have completed a various forms of secondary school education: Institution of the military, the police, nurses, agriculture, forestry, veterinary workers, catering services, tourism, secretarial services and other possible combinations of programmes.

The goals and objectives of higher education include the following: production of manpower for the country, to stimulate the development sound value orientation for the individual and the societies; to ensure critical thinking that stimulate the development of the capacities of individuals and skills to able him/her contribute to the development of the country, and to provide higher education for secondary school graduates. Higher education deals teaching, researching and providing community services. Higher education in Nigeria include Colleges of education, polytechnics, mono-technics, advance professional institutions and the universities.

English language programme is one of the programme offer in the Nigerian higher institutions especially in the universities. Other programme offers in the Nigerian universities include: (1) Administration which include management and management technology; (2)Agriculture- Forestry, Fisheries, and Home economics; (3) Arts, (4)Basic medical and health sciences, (5) Education and other education related programme; (6) Engineering programme and programme in Technology; (7) programme in Environmental Sciences; (8) Law programme; (9) programme in Pharmaceutical Sciences (10) Medicine and Dentistry programme; (11) Science programme; (12) Social Sciences programme; (13) Veterinary Medicine programme. English language programme in recent times in the Nigerian higher institutions is facing many challenges which ranges from poor supervision to poor administration. This article is aimed to discuss the challenges facing the administration of English language programme in the Nigerian higher institutions.

\subsection{Concept of Administration}

Administration is the application of human and materials resources in an effective and efficient manners to realize the objective of an institution. Administration is the utilization of institutional 
resources to actualize the institutional objectives. Administration is the application of organization human and material resources to realize the organizational goals within a set time. Administration deals with arrangement of institutional resources to coordinate and actualize the institutional goals.

Administration in its totality as a process which entails the utilization of human, financial and material resources in maximizing the realization of goals and objectives (Ogbonnaya 2003).

School administration is the process of arrange all educational resources, putting each resources where it ought to be used and coordinating both the human and materials resources for purpose of realizing the objectives of the school. School administration also deals with the effective and efficient utilization of school resources to actualizing the school programmes. School administration look at the effective allocation, supervision and organization of school resources to realize the objectives of the educational institutions. The objectives of school administration include; to plan the educational programme, to design policies to direct the implementation of educational programme, to organize curriculum for the school, to eliminate educational waste, to ensure effective allocation of education resources, to ensure effective supervision of educational resources and to ensure deliver of quality education.

The others objectives of school administration include: (a) to realize the objectives of educational system (b) to ensure proper coordination of human resources (c) to ensure effective and efficient application of both human and materials resources in the management of education (d) to eliminate wastages in the management of education (e) to promote accountability in the management of education (f) to ensure effective plan action for the implementation of educational programme $(\mathrm{g})$ to ensure quality policies that will aid the management of educational programme.

Higher institutions administration in Nigeria takes two dimension. The external and internal administration. The external administration deals with supervision of the institutions through the agencies established by the government such as the National Universities Commission (NUC) for universities, colleges of education National commission for colleges of education (NCCE) while the National Board for Technical Education for the polytechniques (NBTE).

These agencies ensure quality, standard, effective programme accreditation and supervision in all the higher institutions in the country. The internal administration is handled by the school administrators who are appointed by the government to coordinate the activities of the institutions with support from management team and governing councils.
English language programme administration is the systematic ways of arranging resources to implement English programme with the objectives of actualizing the objective of English programme in the educational institutions. The administration of English language programme include plan to implementation of the programme, allocation of human and materials resources for the implementation of the programme, supervision of the human resources and organize the curriculum and instructional materials for the implementation of the programme.

\subsection{Concept of English Language Programme}

English language programme is an art programme. English language programme is one of the prominent programme offer in the Nigerian higher institutions. English language is among the programme offer in the Nigerian higher institutions. It is offered at both the first degree, master and PhD Level with different specializations.

The objectives of English language programme in the higher institutions include: to help students learn and acquire communicative competence in writing and speaking of English language; to help students master English language in term of usage to enable him/her achieve self -actualization and self-expression; to train the students in different aspect of English language which include such as business communication, legal communication, electronic broadcast media, print journalism, advertising and sports commentaries, book publishing, and biography writing. The others objectives also include; to prepare the students to pursue postgraduate studies in English Language, Linguistics, and to take up teaching and research at the appropriate level of education; to help the student to be equip with linguistic knowledge of the English Language, study of its sound system, its lexicon, its syntax, semantics and application.

English is an irascible language according to Owolabi \& Nnaji (2013) as far as development is concerned because "for any nation particularly in the 3rd world to be relevant and derive the maximum benefit from the opportunities that abound in every area of human need, for personal advancement and national development, English is a sine qua non". This is why English continues to hold sway as the language of development in most developing nations of the world, and even in some developed nations of Asia, where it is learnt and used as a foreign language (Owolabi \& Nnaji,2013. Olusoji (2012) observed that English language contributes immensely to the rapid growth and development experienced in Nigeria. Danladi (2013) submitted that English language plays a crucial role in the social, political and economic life support of the people in a given geographic entity. In spite of all perceived roles of English language to humankind, an all-embracing interpretation of its' continues to elude us due to the complexity of its structure and the functions it performs. 


\subsection{Problems Facing Administration of English language Programme in Nigerian Higher Institutions}

There are many problems facing the administration of English language programme in Nigerian higher institutions and some of the problems include; inadequate funding, inadequate English language lecturers, inadequate English language laboratories, poor research in English language programm, braindrain, strike actions, poor capacity development of English language programme lecturers and institutional corruption.

\subsection{Inadequate Funding}

Inadequate funding is a major problem facing the administration of English language programme in the Nigerian higher institutions. The annual budgetary allocation for the administration and management of English language programme in the faculties and departments of English language across the various higher institutions in the country is not adequate. Inadequate funding of higher institution's programme is not only affecting the department of English language but common to all the programme in the higher institutions. Generally, the higher institutions in Nigeria are underfunded and this is directly and indirectly affecting the various programme they are offering. Ogbondah \& Ewor,(2016) also submitted that one of the major challenges facing the management of this sector of education is inadequate funding. The budgetary allocation devoted to education has been considered to be grossly inadequate considering the phenomenon increase in students' enrolment and increasing cost, which have been aggravated by inflation. A serious problem confronting Nigerian public university education today is that of scarcity of fund. Government financial policies on education have therefore been subjected to constant review with the intention of allocating more resources to university education., Okoli, Ogbondah, \& Ewor, (2016), Ogbondah (2010) and Uzoka, (2007) all are in agreement that inadequate funding is a major problem facing the university education in Nigeria.

\subsection{Inadequate English Language Lecturers}

Academic staff are very strong member of the higher institutions. Academic staff are found everywhere department in the higher institutions. The roles of the academic staff cannot be underestimated in the development of the higher education in Nigeria. It is unfortunate that there are shortage of academic staff in many Nigerian higher institutions. This inadequacies is common in the department of English language and other departments. Inadequate lecturers in most department of English language is one of the major problem preventing the effective administration of English language programme. The NEEDS, (2014) on the assessment of higher institutions in Nigeria revealed that majorities of the higher institutions are facing problem of staff shortage. The report indicated that there were 37,504 academic staff in the 74 public universities in the country. The number compare to the student population is inadequate. The shortage of the academic staff resulted to the high students-teacher ratio in most of the universities in the country. For instance, University of Abuja had staff to student ratio 1:122, Lagos state university had a ratio 1:144 and National Open University had a ratio 1:363. The report also showed that $43 \%$ of the lecturers in the Nigerian universities had $\mathrm{PhD}$ while other have less qualification. The reported also revealed that only $50 \%$ of the academic staff have required skills and pedagogical skills, counselling and ICT competencies required for efficient service delivery in tertiary institutions. The report indicated that the shortage of lecturers in majorities of the higher institutions are in the area of sciences, engineering, medicine and surgery, law, early child education, special education etc. The inadequate lecturers in majorities of the higher institutions in the country is responsible for the falling standard of higher education. There are many reasons responsible for shortage of academic staff in the Nigerian public schools, some of the reasons include; low salaries and poor motivation compare to other institutions in the country where they pay high salaries and allowances. Teaching of large classes and rising workload in the universities are also some of the reasons. Brain-drain and poor working environment and lack of manpower planning for higher institutions in the country. The Nigerian higher institutions need about 22,496 teachers to improve the quality of teaching and academic service delivery in the higher institutions (Needs, 2014). No any meaningful administration can take place in the absent of adequate professional teachers. The lack of adequate professional teachers in the Nigerian public schools is a major challenge to effective administration of administration in the country.

\subsection{Inadequate Infrastructural Facilities}

Inadequate infrastructural facilities is another challenges facing the faculties and departments of English language and is affecting the administration of the English language programme. According to the National Universities Commission (2007), A department should have the following have resources: personnel, physical facilities (space and equipment) and library and information resources. Inadequate infrastructural facilities is one of the problem facing the department of English language in many higher institutions in Nigeria.

Okebukola, (2005) reported the need assessment survey of national universities commission and identified the following: (a) only about $30 \%$ of Nigerian students' population has adequate access to classrooms, workshop, lecture halls, laboratories and libraries. (b) Deficient libraries in terms of currency and number of books, journals, and electronic support facilities. (c) Inadequate academic calendar resulting 
from staff unions' industrial action premised on low salary, wages/welfare and students strikes often time related to inadequate facilities. (d) Lack of practical experience, often times resulting from deficient facilities. The above listed factors are all challenges to full implementation of higher education policies in Nigeria. Ojo (2018), John, (2016), Udida , Bassey, \& Udofia, (2009) also agreed that inadequate infrastructural facilities is a problem facing the universities.

\subsection{Poor Research in English Language Programm}

Poor research is another major problem affecting the department of English language programme in the Nigerian higher institutions. The funding of research programme in the Nigerian higher institutions is poor and this is affecting many programme including the English language programme. The government have not been funding the research programme of the higher institutions adequate. Saint, Harnett and Strassner (2003) submitted that Nigeria ${ }^{\text {ee }}$ s low research output is probably a reflection of the low priority accorded research and development by government decisionmakers and that Nigeria"s federal University System spends only $1.3 \%$ of its budget on research.

Okujagu (1998) disclosed that research programme is not well founded so as to have the impact it should have. Funding of research programme in the universities generally is inadequate. Fatunde (2007), Donwa, (2006) and Okebukola, (2004) all agreed that inadequate funding is a major problem facing research development in Nigerian universities.

There are many factors responsible for the poor research development in Nigerian higher institutions and some of the factors include; poor participation of private sectors in the research programme of the universities, inadequate funding from the government, diversion of research funding, lack of infrastructural facilities and brain-drain.

\section{Brain-Drain}

Brain-drain is another challenge facing the administration of English language programme in the Nigerian higher institutions. Many experienced and qualified academic staff are leaving the country to abroad for a better job offers. The migration of the academic staff especially in the English language departments is affecting the implementation of teaching programme in the various higher institutions across the country.

Oni (2000) observed that many experienced and young lecturers are fleeing from the frustration of university life into more rewarding and more challenging sectors of the economy and even migrate to over-sea countries. The result of the faculty exodus is observed in the quality of graduates that our universities produce.

\subsection{Strike Actions}

The strike action embarked upon by the different union groups in the higher institutions in the country is affecting the administration of many programmes specially the English language programme. Okoli, Ogbondah \& Ewor,(2016) observed that it has become a known fact that students across various universities in Nigeria are constantly faced with industrial actions embarked upon by the Academic and Non-Academic Staff Unions of various institutions. The disagreement or lack of understanding between government and unions arising from non-implementation of agreement reached, often results in deadlock that usually disrupts academic calendar. As academic activities are suspended for a long period, the students reading abilities fell. Even the previous knowledge acquired is even forgotten by some students. This mostly turns some students into certificates seekers than knowledge seekers. English language programme needs a stable and conducive environment for effective administration to take place. Asiyai (2005a), Asiyai (2006b) Ahunanya and Ubabudu (2006) established that strike actions is one of the major problem facing the university system in Nigeria

\subsection{Poor Capacity Development of English Language Programme Lecturers}

Poor capacity development of English Language Programme lecturers is another big problem facing the administration of the English language programme in many higher institutions in the country. Lecturers needs training and retraining programme to be on top of their fields. Lecturers employed in the Universities are expected to enjoy training benefits. Bernadette\& Ukaegbu, (2017) did study on impact of poor implementation of welfare policies on training and development on the performance of academic staff in selected federal Universities in South-South Nigeria was carried out to examine the extent to which poor implementation of welfare policies on training and development impacts on the performance of workers in the selected Federal universities in South- South Nigeria. The equity theory was used to explain the variables. Interviews were conducted among 51 workers and the reports were analysed qualitatively. The study discovered that, whereas there are good welfare policy statements in the study area, the level of implementation of these policies were poor. Furthermore, over $90 \%$ of the respondents insisted that full implementation of welfare policies would have positive impact on workers ${ }^{\text {ee }}$ performance to a very large extent. The results further indicated that there have been very few in-house and outside training programmes in the study area. A total of $87 \%$ of respondents agreed that poor level of implementation of welfare policies on training and development is a source of discouragement which have negatively affected academic performance of both teaching and non-teaching staff and have led to poor service delivery in our Universities. As part of this study, fifteen (15) 
laboratory technologists from the five selected federal Universities under study were interviewed and the following are the list of the basic issues that affected their performances as gathered from them: Lack of regular internal training and external training which are necessary to constantly and regularly updates their skills, knowledge and technology to enhance research; Lack of sponsorship for international conferences even when they sponsor themselves, the funds were not remitted thus, the interest in attending conferences are gradually reducing in some of the federal Universities under study whereas there is an available welfare package for conferences and research development domiciled in the federal University but not implemented appropriately (Bernadette\& Ukaegbu, 2017).

\section{Institutional Corruption}

Institutional corruption is not new to the public institutions in the country. Corruption have penetrated all most all the public institutions in the country in including education. Corruption is one of the major problem facing the programme development in the Nigerian higher institutions. Institutional corruption is the problem preventing effective administration of programme like English language programme in Nigerian higher institutions because funds allocated for provision of infrastructural facilities and services in the management and implementation of educational programme are been diverted by officers or political office holder within the institutions. The common forms of corrupting in the Nigerian educational institutions is fund diversion. Corruption on fund diversion have been reported in all the forms of education in Nigeria. Ogunode, \& Abubakar, (2020), Ogbondah (2010) and Dare (2008) also submitted in their respective papers that corruption is a challenge facing the higher institutions in Nigeria.

\section{Way Forward}

To solve this challenges, this article recommends: that the government should increase the funding of English language programme, employment of more English language lecturers, provision of adequate infrastructural facilities, implementation of agreement with unions, effective staff development programme and effective motivation policy to prevent brain-drain.

\subsection{Increase the Funding of English Language Programme}

For effective administration of the English language programme in the Nigerian higher institutions, the government should increase the funding of higher education to enable the higher institutions administrators to also increase the funding of the English language programme in the various institutions.

\subsection{Employment of More English Language Lecturers}

To achieve the objectives of the English language programme in the Nigerian higher institutions, there is need for the government to direct the various higher institutions to employ more academic staff especially in the departments of English language.

\subsection{Adequate Infrastructural Facilities}

The government should provide more infrastructural facilities in all the higher institutions in the Country. This will enable the school administrators to allocate more classrooms, halls, offices, tables and chairs etc to the various faculties and departments in the schools.

\subsection{Implement Union Agreement}

The government should implement all the agreement signed with various union groups in the various higher institutions. This will help to maintain stable academic programme in all the higher institutions.

\subsection{Effective Staff Development Programme}

The government should ensure effective staff development programme for English language teachers in the Nigerian higher institutions. This will enable department of English language to have adequate lecturers.

\subsection{Motivation of Lecturers}

The government should motivate the academic staff and increase their welfare packages. This will prevent barin-drain problem facing the higher institutions in the country.

\subsection{Fight Institutional Corruption}

Institutional corruption in the educational institutions is one of the major factor responsible for the poor quality of education in Nigeria. The government should use all it anticorruption institutions in the country to fight corruption in the ministry of education so that funds budgeted for capital and recurrent services can be effectively used for the implementation of the projects and programme in the educational sectors.

\section{Conclusion}

The article discussed the problems facing the administration of English language programme in Nigerian higher institutions. Secondary data was used to support the points raised in the article. The secondary data were sourced from print material and online publication by recognized institutions and individual author. There are many problems facing the administration of English language programme in Nigerian higher institutions and some of the problems include; inadequate funding, inadequate English language lecturers, inadequate English language laboratories, poor research in English language programm, brain-drain, strike actions, poor capacity 
development of English language programme lecturers and institutional corruption. To solve this challenges, this article recommends: that the government should increase the funding of English language programme, employment of more English language lecturers, provision of adequate infrastructural facilities, implementation of agreement with unions, effective staff development programme, effective motivation policy to prevent brain-drain and fight all the institutional corruption in the higher institutions.

\section{Acknowledgement}

I appreciate all the respondents, my family and my colleagues that supported me in the course of carrying out this project. I want to appreciate the editor team of REILA journal for their kindness and support to publish this paper.

\section{References}

Akpan B.B. (2008). "Nigeria and the Future of Science Education”. Oluseyi Press Ltd Ibadan.

Asiyai R. I. (2005a). Trade union disputes and their perceived impacts on the university system in Nigeria. PhD Thesis, Delta State University, Abraka.

Asiyai R. I. (2006b). Variables inducing trade union disputes in Nigerian universities. Nigerian Journal of Guidance and Counseling 11(1): 146-154.

Bernadette C.N \& Ukaegbu, O .E (2017) Impact of Poor Implementation of Welfare Policies on Training and Development on the Performance of Academic Staff in Selected Federal Universities in South-South Nigeria. International Journal of Scientific Research and Management (IJSRM). 5(12) 7718-7729

Donwa, P. A. (2006). Funding of Academic Research in Nigerian Universities. A paper presented at the UNESCO forum on Higher Education Research and Knowledge creation. November 29-December 1, 2006. Retrieved from http://portal.unesco.org/education/fr/files, July, 2009.

Danladi S. S. (2013). Language policy: Nigeria and the role of English language in the 2 st century. European Scientific Journal, 9 (17).

Evue A. O. (2013). Challenges facing the teaching of English language in secondary schools in Aniocha south local government area of Delta state Nigeria. African Education Indices, 5 (1).

Egwunyenga, E. J. (2008). Dystrophies and Associated Crisis in Research and Academic Publication in Nigerian Universities. Anthropologist 10(4), $245-$ 250 .

Fatunde, T. (2007). Nigeria: Researchers want more funding. Retrieved from http://www. universityworldnews.comparticle, July, 2009.

Federal Republic of Nigeria (FRN) (2014). National policy on education (4th Ed.). Lagos: NERDC press.

John, F. (2016). University development in Africa, the Nigerian experience. Lagos: Light Press.

Needs, (2014). Needs assessment in the Nigerian education sector. International organization for migration, Abuja, Nigeria.

Nwankwoala, H. N. L. (2016). Fundamental facts in educational administration and supervision. Port Harcourt. Harey publications.

Nwachukwu, C.O. (2008): “Tackling the Challenges of Gender Equity in Science Education: Focus on Classroom Interactions for Sustainable Development". A paper Presented at the 1st National Conference of Nigerian National Association for Gender Equity. Port Harcourt Nigeria, March 2008.

Okoli, N. J., Ogbondah, L., \& Ewor, R. N. (2016). The History and Development of Public Universities in Nigeria Since 1914. International Journal of Education and Evaluation, 2(1): 60-73.

Ogunode, N. J., Yiolokun, I. B \& Akeredolu, B. J (2019) Nigerian Universities and their Sustainability: Challenges and Way Forward Electronic Research Journal of Behavioural Sciences, Volume 2 (2019)

Okebukola P.A. (2005). Quality Assurance in the Nigerian University System. Nigerian Journal of Curriculum Studies 12(3), 1-5.

Okebukola, P. (2004). Strategies for Stimulating Researches and Development in Nigerian Universities. Nigerian University Chronicles 12 (2), 17-18.

Okujagu, T. N. (1998). Research paradigms and trends in Sociology and education. Port Harcourt: Minson.

Orukotan, A.F. (2007). "Curriculum Enrichment of STM Education as a Basis for Sustainable Development". STAN 50th Anniversary Conference Proceedings. 32-35.

Oni, B. (2000). Capacity building effort and brain drain in Nigerian Universities, Ibadan: NISER.

Nwagwu, E. T. Ehiametalor, M. A. Ogunu, and Mon Nwadiani (eds). Current issues in educational management in Nigeria. A publication of the Nigerian Association for Educational Administration and Planning [NAEAP].

Ojo, A. A. (2018). Higher Education in Nigeria. Being a Paper presented at Education in Africa Day, held at House of Commons Palace of Westminster, London. 
Odetunde, C. (2004). The state of higher education in Nigeria. retrieved (4/2/2004) http://www.Nigeriadeltacongress.com/sarticle/state-of-highereducation

Obanya, P. (1999), Higher Education for an Emergent Nigeria: Faculty of Education, University of Ibadan 5th Anniversary Lecture, Ibadan. Heinemann Education Books (Nigeria Plc)

Owolabi D. and Nnaji C. I. (2013). The English language and the mass media as tools for sustainable development in multilingual nations. International Journal of language and linguistics, 1 (4), 124-130.

Olusoji O. A. (2012). Effects of English language on National Development. Greener Journal of Social Sciences, 2 (4), 134-139.

Peretomode VF, and Chukwuma RA (2007) Manpower development and lecturers' productivity in tertiary institutions in Nigeria. Journal of Education Studies, English Edition Poland, 5-11.

Romina I, A (2013) Challenges of Quality in Higher Education in Nigeria in the $21^{\text {st }}$ Century. International Journal of Educational Planning \& Administration. 3, (2), 159-172

Salisu, R.A. (2001). The Influence of School Physical Resources on Students Academic Performance. Unpublished M.Ed. dissertation, department of Educational Administration, University of Lagos Nigeria

Saint, W., Hartnett, T. A., \& Strassner, E. (2003). Higher education in Nigeria: A status report. Higher education policy, 16(3), 259-281.

Teevno R. A. (2011). Challenges in teaching and learning of English at secondary level class X. International Journal of Human Resource Studies, 1(2), 27-35.

Udida, I. A., Bassey, U. U, Udofia, I. U. \& Egbona, E. A.(2009). system performance and sustainability of higher education in Nigeria.

Saint, W., Hartnett, T. A., \& Strassner, E. (2003). Higher education in Nigeria: A status report. Higher education policy, 16(3), 259-281.

Uzoka, N.E. (2007). Funding of vocational programmes in Lagos state secondary schools. A journal of the Department of Educational administration, Faculty of Education, University of Lagos. 3 (1), 77-88.

Bollag, B. (2004). Improving tertiary education in SubSaharan Africa: Things that work. World Bank. 